\title{
Governing Legal Embodiment: On the Limits of Self-Declaration
}

\author{
Chris Dietz ${ }^{1}$ (D)
}

Published online: 2 May 2018

(C) The Author(s) 2018

\begin{abstract}
This article presents the first empirically-based and theoreticallyinformed investigation of the effectiveness of the 'self-declaration model' of legal gender recognition in Denmark, the first European state to adopt it. Drawing upon analysis of legislative materials, as well as interviews with stakeholders in the legislative process and trans and intersex legal subjects, it contends that self-declaration is not without its limitations. By conceptualising embodiment as an ontological and epistemological process of becoming, and emphasising the institutional dimensions and effects of such processes, it demonstrates that self-declaration may not address the complexities of legal embodiment, particularly concerning restrictions on trans and intersex people's access to health care. The article's empirical findings are directed towards the policymakers and activists tasked with shaping reforms of gender recognition legislation in the UK and elsewhere. The analytical agenda it develops may be adopted, and adapted, by scholars working in this area and other regulatory contexts.
\end{abstract}

Keywords Denmark $\cdot$ Embodiment $\cdot$ Gender $\cdot$ Recognition $\cdot$ Self-declaration · Trans

\section{Introduction}

This article interrogates the 'self-declaration model' of legal gender status through the lens of embodiment. Self-declaration permits legal subjects to make a formal declaration of their gender status, and have this recognised in civil registration

Chris Dietz

c.p.dietz@leeds.ac.uk

1 Centre for Law and Social Justice, School of Law, University of Leeds, Leeds LS2 9JT, UK 
systems. It is widely considered 'the optimal gender recognition model' (Dunne 2015, 539). Yet while the list of states that have adopted it increases-with Argentina, ${ }^{1}$ Denmark, ${ }^{2}$ Malta ${ }^{3}$ Colombia, ${ }^{4}$ the Republic of Ireland, ${ }^{5}$ Norway, ${ }^{6}$ and Belgium $^{7}$ having done so, and Sweden ${ }^{8}$ on course to follow-there remains a gap in the literature concerning how effective self-declaration has been at meeting the needs of subjects who do not identify with the gender they were assigned at birth. Hence why the United Kingdom (UK) government responded to the Women and Equalities Committee (2016) recommendation to update the Gender Recognition Act (GRA) 2004 'in line with the principles of gender self-declaration that have been developed in other jurisdictions' (14) by stating a preference 'to see more evidence on the case for change and the implications of [...] moving to a self-declaration process' (Government Equalities Office 2016, 11). This article addresses this deficit for the benefit of the legislators, policymakers, campaigners, and activists involved in shaping proposed reforms.

Unlike previous discussions about the limitations of self-declaration-which have centred upon fears of 'fraud or misuse' (Dunne 2015, 538) - this article illustrates how reforms may fail to meet the needs of the gender-diverse populations they purportedly benefit. By identifying points of dissonance between the stated intentions of the campaigners and legislators professionally involved in implementing self-declaration in Denmark in 2014 and the experiences of subjects governed in accordance with them, the effectiveness of self-declaration is challenged from an embodiment perspective. Focusing on embodiment moves beyond the question of how bodies are produced by discourse (Foucault 1998), to consider affective aspects of regulation. Feminist legal scholarship stresses the subjective, intersubjective, material, and symbolic aspects of embodiment (Fletcher et al. 2008). Alongside these, this article emphasises the institutional factors which are key to understanding how embodiment is affected by, and affects, regulatory power-knowledges. If embodiment is understood as the moment when ontology (what I am) meets epistemology (how I identify and am identified), this article addresses the specifically institutional effects of such processes. When institutional regulations coalesce, they significantly affect the 'dynamic encounter between flesh and world' (Garland-Thomson 2011, 592) which grounds practices of embodiment. Moving beyond analysing which

\footnotetext{
1 Gender Identity Law 2012 (Identidad de Genero Ley 26.743) (AR).

${ }^{2}$ L 182 Law amending the Act on the Central Person Registry (11 June 2014) (L 182 Lov om andring af lov om Det Centrale Personregister) (DK).

3 Gender Identity, Gender Expression and Sex Characteristics Act 2015 (MT).

4 Order \#1227 of 2015 (Decreto 1227 de 2015) (CO).

5 Gender Recognition Act 2015 (ROI).

674 L Law amending the legal gender 2016 (74 L Lov om endring av juridisk kjønn) (NO).

7 Act reforming regulations relating to transgender persons concerning amendment of the registration of sex in civil status records and its effects (Loi réformant des régimes relatifs aux personnes transgenres en ce qui concerne la mention d'une modification de l'enregistrement du sexe dans les actes de l'état civil et ses effets) (BE).

${ }^{8}$ Government Inquiry, Juridiskt kön och medicinsk könskorrigering: Betänkande av Utredningen om åldersgränsen för fastställelse av ändrad könstillhörighet (SOU 2014: 91) and Transpersoner $i$ Sverige: Förslag för stärkt ställning och bättre levnadsvillkor (SOU 2017: 92) (SWE).
} 
bodies are or are not recognised in legislative frameworks allows legal embodiment to be reconceptualised as an ongoing process which produces normative bodies and behaviours, and shapes the conditions and possibilities for embodied resistance.

The article is structured into four parts. The first part describes the methodology employed within the empirical research. The second explores the intentions behind, and contexts which shaped, the adoption of self-declaration in Denmark. Herein, self-declaration is positioned in relation to contemporaneous developments affecting the accessibility of health care. The third section lays out the article's theoretical framework which focuses upon how legal embodiment is affected by the governing assemblage of which self-declaration legislation is a constitutive part. Legal embodiment addresses the problem of mind/body dualism, which — as the third and fourth sections demonstrate-has come to permeate Danish regulation. The 'wrong body' narrative is shown to be a crucial point of consensus between otherwise apparently diverging civil and medical reforms. The article concludes by discussing the complexities of trans embodiment which have yet to be addressed in Danish law, as the needs of embodied legal subjects are truncated and ultimately neglected.

\section{Methods and Ethics}

The article draws upon doctrinal analysis of legislative materials; including parliamentary debates, ${ }^{9}$ and the explanatory comments drawn up to accompany the selfdeclaration Bill. ${ }^{10}$ It is also informed by semi-structured interviews conducted with 33 respondents-comprising 14 trans people, 1 intersex person, 11 activists and campaigners, and 7 other stakeholders (including 1 politician, 4 civil servants, and 2 medical practitioners) - over the course of a 3-month fieldwork visit to Denmark in 2015. 25 interviews were conducted in person, and 8 by telephone. Some, but not all, of the activists interviewed are also trans or intersex people (and vice versa). While an attempt was made to ask the respondents different questions depending upon whether they were being interviewed in a personal, professional, or political capacity, this proved impossible to enforce strictly (given the interdependence of these spheres).

The 15 respondents interviewed about their experiences of gender regulation in Denmark were recruited by a call for respondents, posted by activists and campaigners on their organisations' social media pages. Beginning interviews with activists and campaigners facilitated a 'snowball' sampling strategy (Arksey and Knight 1999), whereby initial respondents were asked, at the end of each interview, (1) if they could recommend any professional contacts whom it would also be worth interviewing, and (2) if they would share the call for respondents on their mailing list and social media pages. Any distinction between 'gatekeepers' and 'participants' became blurry, as early interviewees were positioned as gatekeepers to subsequent

\footnotetext{
9 Folketingstidende 20 May 2014, 91. møde, kl. 17:45.

10 Bill for amending the Act on the Central Person Registry (30 April 2014) (Forslag til Lov om aendring af lov om Det Centrale Personregister) (DK).
} 
respondents from within their organisations. The methods literature suggests that the initial stages of the access process are likely to involve 'negotiation' between the researcher, gatekeepers, and research subjects (Madden 2011, 59). As all interviews were conducted amicably, this strategy was employed quite successfully.

While some of the organisations provide a platform for discussion that takes place almost exclusively online, others host regular events and meetings. Some also campaign on a national level. Sharing the call for respondents with a variety of groups ensured that it would be seen by people with differing levels of political involvement, and varying degrees of access to trans communities. Though the sample would never be representative, this constituted an attempt to ensure some demographic diversity. However, one drawback with recruiting digitally is that prospective interviewees without access to social media (or the internet more generally) are excluded. Deciding not to have the call for respondents translated into Danish will also have limited its reach to English speakers. As people educated in Denmark in the post-war era are highly proficient in English, ${ }^{11}$ this may have specifically affected the recruitment of older people (only one over the age of 50, none over 60) and recent migrants (only two, from other countries within the EU). It may have had a knock-on effect upon the recruitment of non-white interviewees, who were not well represented (only one interviewee identified their ethnicity as 'Asian'). On balance, it was decided that it was important to be clear that the interview could not be conducted in Danish (given a lack of both Danish language skills, and the resources to pay for live translation). The fact that one activist declined an interview request because it would be conducted in English suggests that other, self-selecting, respondents may have been deterred from responding. This highlights the limitations of conducting interviews overseas without being fluent in the language.

At the beginning of each interview, respondents were informed that the consent process would be 'ongoing' until the point of publication. They were also assured that they should not feel obliged to answer any questions that made them feel uncomfortable. All respondents were offered the chance to participate anonymously, and were asked to pick a pseudonym to which their responses could be attributed in any subsequent publications. Not all respondents took up this option. Some requested that their names be used for political reasons, including one interviewee who made a specific request to have their name printed in full to facilitate future activism. After briefly discussing the associated risks, a decision was made to honour this request to avoid perpetuating the 'transphobic myth' that being trans is something that one should hide, or be ashamed of (Raun 2010).

\footnotetext{
11 Denmark was ranked third in the world in the Education First English Proficiency Index 2015; 'The world's largest ranking of countries by English skills' (Education First 2015) http://www.ef.edu/epi accessed 2 September 2016.
} 


\section{The 2014 Reforms}

Since 1968, each person registered as residing in Denmark has been allocated a 10-digit social security number in the Central Person Registry (CPR) system. In accordance with the 'odd/even rule', the final digit of this number determines the person's legal sex/gender. ${ }^{12}$ If the final digit is odd, the person's gender status is certified as male; when even, it is female. Since the Danish Parliament adopted the 'self-declaration model' of legal gender status in June 2014, any official resident is now permitted to declare 'an experience of belonging to the other sex/gender'. ${ }^{13}$ The applicant is assigned a new CPR number, without further conditions, provided they confirm that this desire remains unchanged following a 6-month 'reflection period'.

This effectively permits trans people to be issued with a new CPR number without having to first undergo surgical castration for the first time in Danish history. ${ }^{14}$ Hence why the reform was welcomed by almost all interviewees. Yet even in the most optimistic of accounts, positivity around the law was mitigated by contemporaneous reforms taking place in the Danish health care system. Only 7 months after the adoption of self-declaration, the Danish Ministry of Health (Ministeriet for Sundhed og Forebyggelse) published a set of formal medical guidelines codifying that all 'sex/gender modification treatments" ${ }^{15}$ (including hormone replacement treatment and various surgical operations) could be authorised only by a 'multidisciplinary team of collaborating specialists in psychiatry, obstetrics/gynaecology and plastic surgery, with special knowledge of transgender patients'. ${ }^{16}$ The effect of these guidelines is to certify a de facto monopoly for authorising such treatments at the Sexological Clinic (Sexologisk Klinik) of the National Hospital (Rigshospitalet) in Copenhagen. This monopoly was originally established in 2012, after a surgeon working in a private hospital had been reprimanded for performing a double mastectomy on a then 15-year-old trans person named Caspian Drumm. ${ }^{17}$ Before 2012, a regulatory loophole allowed trans and intersex people access to treatments other

\footnotetext{
12 I translate the Danish term ' $k \phi n$ ' as 'sex/gender' whenever the distinction is unclear. While not ideal, this does work against the assumption that English-language conceptual divisions are the 'right' ones, and that the absence of an exact parallel in Danish somehow constitutes a 'lack' (Sandford 2005, 622). It may also go some way towards acknowledging that 'gender' often undertakes the 'ideological work of sex' (Sandford 2015). For example, while the GRA 2004 did instigate a shift in legal terminology from 'sex' to 'gender', the object of governance remained much the same (Cowan 2005). This coincides with Butler's (1990) assertion that sex is 'always already gender' in most circumstances (9-10).

13 L 182 supra $\mathrm{n} 2$ at s 1.

14 Surgical castration involves the removal of the uterus (hysterectomy) and both ovaries (bilateral oophorectomy); or penis (penectomy) and both testicles (orchiectomy) (Munkholm 2015, 153).

15 The compound nouns ' $k \phi n s s k i f t e$ ' and ' $k \phi n s m o d i f i c e r e n d e '$ are interchangeable within official documentation, and I translate both as 'sex/gender modification treatments' to recognise that gender transitions cannot be conceptualised as a singular event (Carter 2014). Though I employ the term 'modification' to refer to various hormonal and surgical procedures understood as constitutive of sex/gender modification treatments, it is not my intention to reproduce instrumentalist understandings of such technologies as 'external' to the body they are mutually entangled with (Sullivan 2014).

16 Guideline no. 10353 on the treatment of transgender patients (19 December 2014) (Vejledning $n r$ 10353 om udredning og behandling af transkфnnede) (DK).

17 For an in-depth account of what became known as 'the Caspian case', see Raun (2016).
} 
than surgical castration through a small number of medical practitioners willing to prescribe hormones and perform minor surgeries on an informed consent basis. ${ }^{18}$ Since this loophole was closed, all new patients and existing patients under the age of 18 seeking access to body modification technologies understood to be constitutive of sex/gender modification treatments have been required to present themselves for psychiatric assessment at the Sexological Clinic.

In the gender studies literature, bodily aesthetics have been described as intrinsic' to gendered embodiment (Davy 2011, 45). All 15 respondents asked about how they had been personally affected by the 2014 reforms reported at least considering the possibility of undergoing body modification. Yet over a third felt unable or unwilling to submit to the officially-sanctioned process of psychiatric evaluation. Some had been turned away from the Sexological Clinic in the past, or had another negative experience that would prevent them from returning there. Others rejected the psychiatric route on principle, as they objected to the way it pathologises gendered embodiment. A purely psychiatric understanding of gender excluded intersex people such as Stephanie Stine Skaaning (Intersex woman, 29), ${ }^{19}$ who described her experience at the Sexological Clinic as follows:

[T]hey're not willing to give me oestrogen, because - in their opinion - it's cross-gender treatment, and therefore trans treatment. [...] I don't think it's cross-gender, but it's cross-gender from my assigned sex, and Denmark - just like any other country in the world - only operates with the female and male categories. It's a problem because there's more variations in the human sex anatomy than just male and female. I think that you should be able to get the treatment that is for you, and not for some social standard.

The process of psychiatric diagnosis has been criticised for scrutinising trans people in relation to out-dated (Hird 2003), middle-class, and white (de Young 2010; Roberts 2012; Metzl and Hansen 2014) gender norms (Davy 2015). These include the depth and assertiveness of the patient's voice, the length and tidiness of their hair and body hair, and their sartorial style. It may also discriminate against subjects who are in receipt of another psychiatric diagnosis, including depression and anxiety. ${ }^{20}$ In contrast with the purportedly inclusive intentions of self-declaration, then, the result of the ongoing relevance of psychiatric diagnosis is that the effect of the 2014 reforms will vary according to a person's age, class, disability, ethnicity, and sexuality.

\footnotetext{
18 Medical practitioners outside the Sexological Clinic were not formally prohibited from performing body modifications other than surgical castration, as the medical guidelines previously concerned only this specific treatment; Guideline no 10077 on surgical castration for the purposes of sex/gender modification (27 November 2006) (Vejledning nr 10077 om kastration med henblik på kønsskifte) (DK).

19 While their concerns did not arise during the legislative process, intersex people were not prohibited from using the CPR law to amend their legal gender status. Denmark permits non-therapeutic medical intervention on children, but intersex people cannot be treated at the Sexological Clinic.

${ }^{20}$ One stated justification for requiring psychiatric evaluation is that it may clarify whether the patient is suffering from 'any concurrent physical or mental disorders (comorbidity) [...] that may contraindicate treatment'; Guideline no 10353, supra n 16 at s 1.
} 
Difficulties accessing health care were repeatedly raised by interviewees uncomfortable with psychiatric evaluation. Sasha (Non-binary, 23) explained that the fact self-declaration had not increased accessibility meant the legislation had been unable to address an important aspect of trans embodiment:

I have mixed feelings about it [...] because instead of focussing on access to health care, or more effective health care, there's a focus on documentation which is less important, in a way. [...] [N]ow - at least in Denmark - you can change your CPR number [...] but the access to health care has got worse.

The decision to centralise access to body modification technologies may even undermine self-declaration's stated intentions; as the possibility of legal gender recognition offers scant consolation to those unable to access body modification technologies - for reasons explained by activist Elias Magnild (Trans Political Forum):

It would never be the first step for anyone to change your CPR number - you would just come in[to] a lot of trouble every time you go out and get work with the wrong CPR number, or the wrong name, that you're not passing as.

Concerns around the possibility of 'passing' suggest that although the CPR law may be formally open to all Danish residents, recognition may be practically inaccessible in the absence of corresponding health care provision. The intention that 'situations will become easier when there is consistency between CPR number and physical appearance $^{, 21}$ is apparently undermined when self-declaration is not complemented by access to body modification technologies. If law ignores the importance of bodily aesthetics, reforms based on the principles of self-declaration may continue to exclude legal subjects wary of amending their legal status without material support.

Such findings, which demonstrate the limitations of the Danish reforms, will greatly interest those tasked with responding to proposals to implement self-declaration in the UK and elsewhere. The GRA 2004 currently requires applicants for gender recognition to be diagnosed with 'gender dysphoria' ${ }^{22}$; also situating trans phenomena within a 'narrative of pathology' (Drescher 2014, 12). Yet as the argument that this constitutes a 'positively Victorian' (Newsnight 2016) 'medicalised' process which 'pathologises trans identities' begins to gain traction within reform debates (Women and Equalities Committee 2016, 14), so could suggestions that the 'uncoupling of law and medical discourse and practice' (Hines 2013, 103) would enable the deconstruction of binary forms of gender regulation. By offering a 'wholly nonmedicalised' model of legal gender recognition (Dunne 2015, 538), self-declaration does appear to 'uncouple' legal and medical regulations of trans status; granting legal effect to a personal declaration of gender status without the need for gatekeepers' authorisation. But even scholars who are critical of the 'medicolegal alliance' created by the GRA 2004 (Davy 2011, 31) acknowledge that even if it were politically viable, disaggregating civil and medical norms risks placing even greater barriers between trans people and body modification technologies (Davy 2015).

\footnotetext{
21 Bill for amending the Act on the Central Person Registry supra $\mathrm{n} 10$.

22 GRA 2004, s 2(1)(a).
} 
This issue is assumed to be particularly marked in countries where trans people are reliant on receiving a quantifiable diagnosis to gain access to financial support through personal health insurance plans (Drescher et al. 2012). Yet analysis of the Danish reforms suggests that separating civil and medical regulatory frameworks could also have an adverse effect in countries, like Denmark, which maintain public health care systems. Though separating out civil and medical jurisdictions appeared to make sense to the politicians, civil servants, and medical practitioners professionally involved in the legislative reforms, the same cannot be said for those personally affected by them. Trans and intersex interviewees saw civil and medical regulation as closely interrelated, and not easily disentangled-particularly where recognition from one regulatory system was understood as dependent upon being authorised by the other. So, although Denmark's decision to adopt self-declaration should be celebrated, the contemporaneous centralisation of authorisation for body modification technologies understood to be constitutive of sex/gender modification demands greater scrutiny than that which it has been previously afforded.

\section{Legal Embodiment}

When the Danish government initially reported its intention to review 'the rules concerning sex/gender modification treatment, including opportunities to have a legal sex/gender change without the need for surgical intervention' (Prime Minister's Office 2011), civil and medical concerns were positioned alongside one another. Yet by 2014 , the two had been disentangled. ${ }^{23}$ This is clear from the mandate issued to the inter-ministerial working group, established, in January 2013, to investigate how the government's policy commitment could be implemented. This working group was tasked with describing existing legal and medical regulations, but was asked to develop proposals only in respect of civil and not medical reforms (Ministry of Justice 2013). Interviews confirmed that this limited mandate was respected in practice, as Grethe Kongstad, speaking on behalf of the CPR Office, explained:

The thought was that everyone should have the possibility [to change their legal gender status]; and those that want to change their bodies - and where they are given permission to do so - of course they should carry on doing so. It's still two different possibilities: to change your CPR [number]; and then to change your body. But of course, that's treated in a whole other system.

The understanding that decisions about how access to body modification technologies ought to be regulated belonged to a "whole other system" than civil law explains why no attempt to evaluate the interim guidelines is described in the working group's report (Ministry of Justice 2014). That health care authorities including the Ministry of Health and the Danish Health and Medicines Authority (DHMA) were represented in the working group will also have helped ensure that this division was respected. As the DHMA representative, Anne Mette Dons, explained in

${ }^{23}$ Following the controversy surrounding the Caspian case, discussed supra $\mathrm{n} 17$. 
an interview, the new medical guidelines were already "in progress at that time anyway", and were merely "stalled" until the working group had published its report. Parliamentary debates indicate that this strategy extended to the parliamentarians supportive of the centre-left coalition government. This became apparent when opposition proposals to include some form of medical assessment (such as a 'regular appointment' with 'one's own doctor' ${ }^{24}$ were dismissed on the basis that this would negate the intention of separating civil and medical regulations. ${ }^{25}$

While such a strategy could be construed as pragmatic-ensuring that people would be able to self-declare their legal gender status without needing to seek the approval of a gatekeeper-it is not beyond criticism. In any situation where the medical profession may be resistant to political developments, this strategy risks ensuring that key issues, including access to health care, can be designated as purely medical and not legal - and positioned outside the scope of legislative change. Conceptually, the strategy is marked by mind/body dualism. Introducing one reform which recognises people's gender status - putatively located in their minds-before certifying another restricting access to body modification technologies hardly reflects a holistic strategy for addressing the complexities of legal embodiment.

Feminist legal scholars have established a long-standing praxis of challenging legislative and judicial attempts to bifurcate regulation of legal subjects' minds and bodies. It has been noted that the two poles of this dichotomy have not been drawn equally — with a hierarchy established to privilege the mind over and above its 'suppressed, subordinated, negative counterpart' (Grosz 1994, 3), the body. Law has itself tended to focus upon the content of minds first and foremost, turning attention only subsequently to the actions of bodies (Naffine and Owens 1997, 12). This explains why physical injury is prioritised over emotional injury in negligence (Conaghan 2013, 227), how intention is used to distinguish between convictions of murder and manslaughter in criminal law (Herring 2014), and how authority over the body can be transferred to others when a person's mind is deemed to be failing by those who assess capacity in social and health care law (Keeling 2016; Clough 2017). Meanwhile, law has also sought to maintain claims to objectivity, distancing itself from bodily concerns; including differences relating to intersections of age, class, disability, ethnicity, gender, and sexuality. Law has thus opened itself up to criticism both for seeking, and failing, to divorce itself from the body; in a paradox described as the founding concern of feminist legal scholarship (Neave 1997, v).

Mapping a trajectory of feminist legal scholarship, Fox and Murphy $(2013,250)$ note that the earliest challenges to mind/body dualism in law involved contesting the ways in which the body had been misrepresented in, or excluded from, legal provisions. Though this turn to 'the body' may have inverted the privilege accorded to the

\footnotetext{
${ }^{24}$ Fatma Øktem, Folketingstidende 20 May 2014, 91. møde, kl. 17:45, 17:51.

25 The spokesperson for the Red-Green Alliance argued that 'legal gender change has nothing to do with the health care system', resisting the opposition's proposal on the basis that to continue to include medical professionals in the reform legislation would be to undermine its purpose: 'The thing that we are trying to do is to separate the legal sex/gender change from the health care system, so it is hard for me to understand why the Liberals want to have a doctor involved in the process'; Stine Brix, Folketingstidende 20 May 2014, 91. møde, k1. 18:02.
} 
mind within the established binary, it did so only within existing dualistic parameters. Where dualism is itself understood to be problematic, an understanding develops that attempts to re-appropriate the terminology of 'mind' and 'body' risk reducing the former to wistful idealism and the latter to blunt materiality (Lacey 1997, 73). In response, it has been suggested that 'embodiment' could be approached as a 'category' rather than an 'object' of analysis (Fletcher et al. 2008, 321), mandating 'a broader focus on lived experience and the question of how we inhabit and experience the world through our bodies' (Fox and Murphy 2013, 256). Attempts to theorise about the body-in an obtusely disembodied manner-are eschewed by embodiment scholars who wish to theorise from embodied experience instead (Williams and Bendelow 1998). In this respect, feminist legal studies of embodiment address how mind/body dualism is reproduced in law, offering insights into how reforms which seek to improve the standing of marginalised subjects-including those who do not identify with the gender they were assigned at birth-fail even upon their own terms. As regulation is not experienced by mind or body exclusively, laws which are particularly dualistic can end up privileging the concerns of one over the other, leaving legal subjects to deal with the consequences of this disjunction.

It is also instructive to note that while formal 'state" ${ }^{26}$ law is important, it is by no means the only authoritative system to affect the conditions of a subject's embodiment. A range of normative institutions_-including the family, the workplace, and the health care system - are also involved in permitting or prohibiting various modes of conduct, and are therefore 'legal' in a pluralist sense (Merry 1988; Harding 2011, 30). So, although legislators should be wary of separating the concerns of the mind from those of the body, this alone will not suffice to ensure that dualistic modes of regulation have been avoided. Where dualism is present in forms of regulation outside of formal law, it may be reproduced-albeit indirectly-by reforms which fail to challenge mind/body splits present in existing forms of non-legislative regulation. In this respect, mind/body dualism cuts across formal statute, affecting embodiment through governing projects undertaken by institutions other than those commonly classified as 'legal'. As they are confronted by reform debates, then, activists and scholars must consider looking beyond the discursive realm (Foucault 1998) to address how governing processes saturate bodies with meaning. ${ }^{27}$ In the context of gender recognition, this demands interrogation of the way in which representations of trans and intersex phenomena have been influenced by institutional regulations. Notable here are medical institutions, whose practices have played a formative role in understandings of gendered embodiment past and present. Laws which ignore, or fail to address, this power dynamic may appear to be doomed from the outset.

The reason for this is that dualistic understandings of mind and body tend to leave one pole of the dichotomy 'undertheorised' (Cowan 2005, 71) in comparison with the other. While conceptions of 'the mind' are subjected to intensive critical

\footnotetext{
${ }^{26}$ Inverted commas are used to challenge the implication that the governance carried out by institutions such as the health care system are not—at least tacitly-linked to 'state' law. For more on the 'internal' legal pluralism of governing assemblages, see Valverde (2015).

27 I am grateful to Olga Cielemęcka for helping me formulate legal embodiment in this way.
} 
analysis, 'the body' is left standing in the 'natural' realm of biology' (Cowan 2005, 71). This phenomenon became apparent within the Danish parliamentary debates. As representatives of the socially conservative parties raised deterministic arguments about the 'objective' 'reality' of 'biology', ${ }^{28}$ parliamentarians from the left neglected to challenge these accounts on their own terms (dismissing them as irrelevant instead). ${ }^{29}$ Debate then bifurcated around the advantages of regulating identity or biology - with no consideration given to how the two might relate. This led to the spokesperson for the Social Democrats, who headed the centre-left coalition government, noting:

I am very happy that this Bill can help to solve a problem which the LGBT community in Denmark has long drawn attention to and wished to resolve. The solution is to have our laws updated so that it will become possible for those who feel like they are trapped in the wrong body to achieve legal sex/gender change. ${ }^{30}$

Interviews suggest that the assumption that legal recognition of a trans person's gender identity will suffice to ensure that they no longer feel 'trapped in the wrong body' may over-emphasise the relative value of civil and medical recognition-or, 'the mind' in relation to embodied concerns. As has been noted, while civil recognition may be formally inclusive, it remains inaccessible for trans and intersex subjects unable or unwilling to amend legal gender status without medical support. Legislative attempts to liberalise the mind are effectively undermined when processes determining access to body modification technologies are not reformed in kind. Meanwhile, concerns about 'passing', and other practical challenges, were raised only infrequently in the Danish Parliament. On the occasions when the government's optimism around the benefits of self-declaration was questioned, such challenges were formulated from a biologically-determinist perspective. So, while politicians on the left prioritised mind over body, those on the right emphasised body over mind. Dualistic framings thus proliferated on all sides, as the 'wrong body' narrative - which suggests that trans people's minds and bodies do not match-was accepted across the political spectrum as capturing the essence of what it is to be trans. $^{31}$

This moment of consensus constitutes the main point of convergence between the 2014 reforms. The 'wrong body' narrative shapes the self-declaration provision,

\footnotetext{
28 The spokesperson for the Danish People's Party argued that 'if you are a man who feels like a woman, you will still be a man biologically'; Pia Adelsteen, Folketingstidende 20 May 2014, 91. møde, kl. 18:14. The Conservative People's Party spokesperson agreed that 'there is an objective link between one's physicality and what one is registered as'; Charlotte Dyremose, Folketingstidende 20 May 2014, 91. møde, kl. 18:46.

29 The Minister responsible for introducing the legislation argued that defining gender did not make 'much sense', as the Bill's purpose was 'quite simple': 'It is about helping a group of people to live the kind of life they wish to live'; Margrethe Vestager, Folketingstidende 20 May 2014, 91. møde, kl. 19:07.

30 Rasmus Horn Langhoff, Folketingstidende 20 May 2014, 91. møde, k1. 18:05.

31 Even the spokesperson for the socially conservative Danish People's Party stated: 'I acknowledge that it is possible for a person to feel like they belong to a different gender, or to be born into the wrong body'; Adelsteen supra n 28 at 18:07.
} 
which requires applicants to declare 'an experience of belonging to the other sex/ gender' ${ }^{32}$ This declaration is understood to be motivated by a 'mismatch between biological sex/gender and the sex/gender which they experience themselves as belonging to and identifying with'. ${ }^{33}$ The same logic underscores the 'transsexualism' diagnosis, which constitutes the barrier to body modification technologies understood as 'sex/gender modification' treatments within the new medical guidelines. ${ }^{34}$ 'Transsexualism' is defined in the World Health Organization's (2015) 'International Statistical Classification of Diseases and Related Health Problems' (ICD-10) as

A desire to live and be accepted as a member of the opposite sex, usually accompanied by a sense of discomfort with, or inappropriateness of, one's anatomic sex, and a wish to have surgery and hormonal treatment to make one's body as congruent as possible with one's preferred sex.

The diagnosis is overtly dualistic, with 'one's body', and 'one's anatomic sex' positioned in opposition to the 'desire to live and be accepted' as a member of 'one's preferred sex' (also construed as the 'opposite sex'). Reference to a 'sense of discomfort' also implies a purely psychiatric conception of gender-in the mind. Following the implementation of self-declaration and the new medical guidelines, reproducing the 'wrong body' narrative has become compulsory for any trans person who wishes to access legal recognition or body modification. The legislative strategy which sought to separate civil and medical recognition hereby ensures the centrality of the 'wrong body' narrative to the regulation of trans embodiment in Denmark.

\section{The 'Wrong Body' Narrative}

Reporting that one has been born into the 'wrong body' is described as a common way for trans people to convey their experiences of trans embodiment (Cowan 2008). This was borne out in interviews. But as opposition to this trope becomes more common among scholars and activists (Schofield 2010; Bettcher 2014; Engdahl 2014), evidence that critiques of the 'wrong body' narrative may be permeating through trans communities was offered by the minority of interviewees. When asked to explain his own personal understanding of trans embodiment, Mark (Transman, 38) responded:

There is something bodily - there is something almost physical - about being trans that other people cannot relate to if they're not trans themselves, which

\footnotetext{
${ }^{32} \mathrm{~L} 182$ supra $\mathrm{n} 2$ at $\mathrm{s} 1$.

33 Bill for amending the Act on the Central Person Registry supra $\mathrm{n} 10$.

34 Guideline no 10353, supra n 16 at s 1 .
} 
makes it extremely difficult when you want to transition - cause you need physical changes. [...] So there's a barrier there. But understanding is complicated because how can you understand being trans? I mean a lot of people say "born in the wrong body" but I wasn't born in the wrong body. A lot of people [...] tend to use that as an explanation: "Yeah, you were born in the wrong body." "Err, nope. This is the right body, it's just some minor details that need a bit of fine-tuning." [...] [P] eople try and understand, but when you don't live it, you don't have a chance of understanding. Even when you are trans, you might not get it.

Mark begins by highlighting the importance of body modification to his transition. That he does so while disputing the 'wrong body' narrative emphasises Hines's (2007) finding that trans people are aware of the need to convey their experience in these terms if they are to be granted access to body modification technologies. Davy (2010) describes trans people's awareness that their biographies might need manipulating if they are to access hormones and surgeries as constitutive of 'reflexive agency' (108). Mark supplements this finding by noting that while the 'wrong body' narrative may have been developed as a way of reducing the complexity of trans embodiment, its intended audience includes not only gatekeepers to body modification and gender recognition but non-trans ('cis') ${ }^{35}$ audiences more broadly. He then adds an epistemological caveat—-that "Even when you are trans, you might not get it"- which gestures toward the possibility that experiences of trans embodiment vary so much that even trans subjects cannot be relied upon to convey the many nuances in their totality. Later in the interview, almost as if to illustrate this point, Mark struggled to describe trans embodiment outside of a dualistic framework, stating:

[T]here is something - when you're a trans person - about body and mind. That's the exact problem; that body and mind don't fit together. And it's so hilarious (in a way) that it can be fixed with hormones and surgery. It's just difficult to get that. It is my body, and there's nothing wrong with it, in that regard, because it can be fixed. But it's just difficult to fix it because of the legal situation.

By falling foul of dualistic framings, and describing trans bodies being "fixed", Mark engages in a discourse which could be considered problematic by those seeking to de-medicalise trans subject positions entirely (Thaemlitz 2015). This point is

\footnotetext{
35 'Cis' is an adjective which refers to people who are not trans. Concerns have been expressed that the term risks perpetuating the myth that just because a person does not actively dis-identify with the gender they have been assigned at birth, they experience stasis-as the Latin root of 'cis-' prefixes things that stay put or do not change property (Enke 2012, 60). Such a-temporal understandings of gender neglect embodied difference, including how bodies develop through life. Yet such labels, however imperfect and generalising, may strategically de-naturalise non-trans subject positions which would be otherwise reified as 'man' and 'woman', or, worse, preceded by the prefix 'bio-' (Aultman 2014). Here 'cis' could help account for the structural advantages people who do not actively dis-identify with the gender they were assigned at birth enjoy in comparison with those who embark upon a (more or less) intentional transition (Lennon and Mistler 2014).
} 
raised not to criticise him for failing to develop a coherent narrative of trans embodiment outside the 'wrong body' narrative; for it is accepted that 'an adequate linguistic framework' (Lacey 1997, 73-74) through which to capture the complexities of embodiment has yet to be developed in a Western 'intellectual heritage' (Grosz 1994, 21-22). But while this particular narrative remains a pre-requisite for accessing legal recognition and medical authorisation, it is impossible to decipher whether it is used 'strategically', or because it simply 'feels right' (Raun 2014, 18).

In exploring the prevalence of the 'wrong body' narrative, Davy (2011) describes subjectivity as dependent upon the construction of a contextually 'coherent' body image, before adding that coherency need not necessarily mean normativity (66). Challenging the idea of having the 'wrong body', Davy (2011) asks: 'At what point is the body right? Can embodiment ever feel right?' (53). Probyn $(1993,4)$ understands selfhood as a mode of holding ontological and epistemological accounts of experience together, before stressing that such accounts must be used with and against each other. On the ontological level, experience identifies the disjuncture that can appear between material and discursive aspects of the social; while on an epistemological level, it invokes analysis of the material-discursive relations formed between that which is lived and that which is merely articulated (22). Ontological moments of recognition-who I am, what I am-are not left as self-evidently constitutive of knowledge, but are 'checked' by 'the epistemological insistence precisely on theoretical exigency and social conjecture from and for which the self is spoken' (Probyn 1993, 30-31).

This formulation of embodiment allows symbolic ideas of bodily integrity — such as 'the right body', or any 'propertied or sovereigntist understanding of embodiment as the subject's ownership and determination of the soma' (Grabham 2012, 3) - to be understood not as valuable in themselves, but for the opportunities that they offer people 'to craft their own sense of identity, to pursue their talents and quite simply, for fostering their 'own' sense of the good life' (Priaulx 2008, 183). Priaulx (2008) adds:

[B]eing able to take one's body more or less for granted (quite irrespective of what one's existing physical state actually is), rather than being conscious of and consumed by one's physicality all the time, is what is best captured by bodily integrity. It is a sense of self, a stable platform for pursuing one's plans, [more] than an actual descriptor of our physicality (185).

This conception of bodily integrity offers one response to Davy's provocation; as being granted a 'stable platform' could allow trans and intersex subjects to develop novel personal (normative or non-normative) narratives of embodiment without dwelling on the question of whether their body is 'right' or 'wrong'. Though such conceptions are not utopian (as they accept that the effect of legal protection will always be limited in practice), they still look beyond present conditions-justifying legal reform in cases where existing policies require, or simply leave, subjects to become 'consumed' by their physicality. For Fox and Thomson (2017), 'embodied integrity' ought to encompass 'not only decisions to modify our bodies but [also] highlight the importance of transcending our bodies' (519). In contrast to more established, and static, ideas of bodily integrity, this dynamic principle values 'the 
mutability and plasticity of bodies'; encompassing not only who we currently are, but also 'who we may become' (Fox and Thomson 2017, 519).

For trans and intersex subjects, the prospect of forgetting one's body, and simply being embodied, ${ }^{36}$ may or may not be achieved via hormones or surgery. However, access to body modification technologies is currently restricted to those who meet a specific set of diagnostic requirements determined by psychiatric assessment. What Hines (2010) calls 'aetiologies of transsexualism' continue to position practices of gender 'as manifest of atypical 'sexed' biological or psychological development', with clear lines etched between normativity and diversity: the 'right' and 'wrong' body (93). Irrespective of any personal complaints that they may have had with their bodies, most interviewees felt that the search for such aetiologies was misguided. When asked how she understands trans phenomena, Kirsten (Female, 57) responded:

You can't explain. That's just how it is. And I don't know what it is, but it's been there all the time [...]. They can come with all their explanations $[\ldots]-$ [locating trans in the] brain or something like that. [But] that doesn't help me anyway - that's not my explanation, that's someone else's explanation. I don't know. [...] I don't care. [...] [M] aybe it's the genes, but they can't find a gene for transgenderism - [...] they haven't found it yet and they don't know the combination. [...] [B]ut if they ever find out, don't fix it!

Similarly, when reflecting on the subtle forms of discrimination-or 'micro-aggressions' (Nordmarken 2014) — that she had experienced, Anita (Female, 46) noted:

[W] hen I am in larger groups of people, I see there are some people that don't want to talk to me - maybe because they don't know what to talk to me about. [...] [T] here's still a lot of people out there who don't even know what transgender is. So, when they see or hear about a transgender person, they don't understand it - but how should they understand it, when I don't understand it?! I don't even know what it is, and why. So, you can't understand it, you just have to accept it that some people are different, and have another background.

Echoing negative and anti-social queer readings of inclusion (Edelman 2004; Berlant 2011; Thaemlitz 2013), ${ }^{37}$ Kirsten and Anita challenge the idea that recognition can or ought to be based upon empathy or understanding. The possibility of coming to a positive 'understanding' of trans and intersex embodiment is dismissed in favour of a more straightforward, unconditional, and perhaps even universal demand for acceptance without pre-requisite-be that in the form of psychiatric assessment or any other measure of deservingness.

For present purposes, this presents a paradox. On the one hand, interviews suggest that embodiment cannot (and perhaps should not) be fully understood. Yet a

\footnotetext{
36 In accordance with Beasley and Bacchi's (2000) suggestion that just as the mind cannot be separated from the body, neither can the self that emerges thereafter: "we' do not 'control' our bodies, [...] 'we' are not separable from our bodies. Indeed we are our bodies' (344).

37 I would also include the work of artist Vika Kirchenbauer, represented by Kunak (2016), here.
} 
lack of understanding of people's practical concerns during the reform process could also be blamed for at least some of the problems that trans and intersex people face. If a deeper understanding of trans and intersex phenomena would not have helped ameliorate these problems, then what would? The embodiment perspective developed in this article suggests that scholars and activists ought to respond to this paradox by acknowledging the complexity of embodiment, without truncating or claiming to understand it in any definitive manner. By eschewing aetiologies of trans and intersex phenomena, and speculations about causality, and insisting that ontological and epistemological dimensions of embodiment are mutually constitutive (Probyn 1993), an embodiment approach accepts that knowledge is always situated, and only ever partial (Haraway 1988). Processes of legal embodiment-constituted by ontological and epistemological processes of institutional becoming-must be understood as ongoing, contingent, and subject to repetition and change.

Accepting this undecidability need not foreclose the possibility of recognition, ${ }^{38}$ or other forms of legislation which support practices of embodiment. But campaigners and activists ought to be wary of reforms which claim to offer recognition while reproducing dualistic framings of trans and intersex phenomena without addressing the embodied concerns of those they purport to benefit. Once civil and medical reforms were distinguished in Denmark, those sympathetic to the concerns of trans and intersex people missed an opportunity to foster bipartisan criticism of medical regulation while seeking to ensure that self-declaration passed into law. ${ }^{39}$ This may have been different had the 2014 reforms been presented as a comprehensive whole. ${ }^{40}$ As they were not, self-declaration failed to address trans and intersex people's embodied concerns. In different circumstances, self-declaration might form part of a wider movement toward the 'depathologisation' (Theilen 2014; Davy et al. 2018), or 'decertification' of gender status (Cooper and Renz 2016). In Denmark, however, authoritative medical discourses around trans phenomena have been left unchallenged, and problems in gaining access to health care remain.

\section{Conclusion}

This article presented the first critical assessment of the effectiveness of the selfdeclaration model of legal gender recognition in the first European state to adopt it. Deploying a legal embodiment perspective, the article identified numerous problems

\footnotetext{
38 This could demand the 'decertification' of gender status; via the abolition of legal mechanisms which assign and certify subjects as male or female at birth (Cooper and Renz 2016).

39 Spokespersons for the Red-Green Alliance and Socialist People's Party did register criticisms of the diagnostic process while debating the L 189 Law amending the Health Act (11 June 2014) (L 189 Lov om andring af sundhedsloven og lov om assisteret reproduktion i forbindelse med behandling, diagno stik og forskning m.v.) (DK); Folketingstidende 20 May 2014, 91. møde, kl. 19:43-19:44 and kl. 20:00.

40 cf Article 11 of the Argentinean Gender Identity Law 2012 supra n 1, which establishes a right 'to access total and partial surgical interventions and/or comprehensive hormonal treatments' on an informed consent basis. Although the Argentinean legislation was cited by the working group, discussion of this provision was notably absent from their report (Ministry of Justice 2014).
} 
faced by those who do not identify with the gender that they were assigned at birth in Denmark. Reading the Danish reforms alongside the insights of feminist legal scholarship, problems with the implementation of self-declaration were traced back to the attenuated understanding of embodiment. As legislation sought to liberalise people's minds without considering their embodied concerns, it failed to address issues such as access to health care. Mind/body dualism was certified within statutory legislation and medical regulations. The article suggests that while self-declaration appears to constitute a model of good legal doctrine when considered at face value, it can be seriously limited when it comes to meeting the substantive needs of trans and intersex subjects. While all Danish residents are now responsible for determining their legal gender status, many have also been left without the necessary support to access the benefits of recognition in practice.

As the list of states that have adopted self-declaration increases, this article offers a timely critical perspective on how this form of recognition may be susceptible to co-optation. Where reforms fail to confront the pathologisation of trans identities-either explicitly (in law) or tacitly (through the demand to undergo sustained psychiatric diagnosis as a pre-requisite to accessing body modification technologies)_-'wrong body' narratives may persist. In such circumstances, it seems unlikely that the embodied concerns of trans and intersex subjects will be met, regardless of legislative intentions. Of course, there are many reasons why a law reform project might fail to meet its purported ends, as discussed in the literature on bio-political governmentality (Spade 2011; Stryker 2014). But even within the frame of reform debates, important insights can be gained from reading the Danish reforms through an embodiment lens-for the benefit of the scholars, policymakers, campaigners, and activists tasked with shaping future reforms.

Of the states considering a move towards self-declaration, the risk of the UK ignoring health care concerns may seem less pronounced than in the Danish context. For instance, the Women and Equalities Committee (2016) focused on both civil and medical regulations in its inquiry. Yet contemporary political contexts, including the National Health Service crisis now eliciting 'humanitarian' concern from the Red Cross (Adamson 2017), are enough to invite scepticism as to how supportive of embodiment reform proposals are likely to be. This article seeks to inform those active within reform debates without shying away from anticipated failings and limitations. It has illuminated various deficiencies in the legislative strategy employed within the Danish reforms by comparing regulatory intentions with the experiences of those governed in accordance with them. In addressing the deficiencies of selfdeclaration, this analysis gestures towards broader debates about the limits of law without advocating or dismissing legal activism or law reform per se.

Looking beyond this specific area, the article suggests that critical studies of the governance of embodiment could benefit from considering the institutional realm as somewhat distinct from the discourses it is producing. This is particularly relevant to specifically legal (albeit legally pluralist) conceptions of embodiment if scholars are to address how embodiment is affected by, and affects, regulatory power-knowledges. A careful framing of legal embodimentas the ontological and epistemological process of becoming a legal subject within complex institutional frameworks - allows scholarship to move beyond analysing 
which bodies are recognised in legislative materials, to address legal embodiment as an ongoing and repetitive process which produces normative bodies and practices and shapes the conditions and possibilities for embodied resistance. Such insights offer a new agenda for feminist and socio-legal research which could be adopted or adapted by scholars working in this area and in other regulatory contexts.

Acknowledgements The doctoral research which this article presents was funded by the Economic and Social Research Council (ES/J500215/1). Earlier drafts were presented at the Interacting Minds Centre for the Study of Cognition, Communication and Choice at Aarhus University in June 2015, and at the Social and Legal Studies Association Conference, at Newcastle University, in April 2017. The author would like to thank organisers and attendees on both occasions. This gratitude extends to all interviewees. Special thanks are reserved for Julie Wallbank, Michael Thomson, Vika Kirchenbauer, and Mitch Travis, as well as the two anonymous reviewers and the Feminist Legal Studies Board, for their feedback and support.

Open Access This article is distributed under the terms of the Creative Commons Attribution 4.0 International License (http://creativecommons.org/licenses/by/4.0/), which permits unrestricted use, distribution, and reproduction in any medium, provided you give appropriate credit to the original author(s) and the source, provide a link to the Creative Commons license, and indicate if changes were made.

\section{References}

Adamson, Mike. 2017. Try Telling Patients on a Trolley This Isn't a Crisis. The Times, 9 January. https:// www.thetimes.co.uk/edition/comment/try-telling-patients-on-a-trolley-this-isnt-a-crisis-cr3dzr3fp. Accessed 22 April 2018.

Arksey, Hilary, and Peter Knight. 1999. Interviewing for Social Scientists. London: Sage.

Aultman, B. 2014. Cisgender. Transgender Studies Quarterly 1(1-2): 61-62.

Beasley, Chris, and Carol Bacchi. 2000. Citizen Bodies: Embodying Citizens-A feminist analysis. International Feminist Journal of Politics 2(3): 337-358.

Berlant, Lauren. 2011. Cruel Optimism. Durham and London: Duke University Press.

Bettcher, Talia Mae. 2014. Trapped in the Wrong Theory: Rethinking Oppression and Resistance. Signs: Journal of Women in Culture and Society 39(2): 383-406.

Butler, Judith. 1990. Gender Trouble: Feminism and the Subversion of Identity. New York and London: Routledge.

Carter, Julian. 2014. Transition. Transgender Studies Quarterly 1(1-2): 235-237.

Cooper, Davina, and Flora Renz. 2016. If the State Decertified Gender, What Might Happen to its Meaning and Value? Journal of Law and Society 43(4): 483-505.

Clough, Beverley. 2017. Disability and Vulnerability: Challenging the Capacity/Incapacity Binary. Social Policy \& Society 16(3): 469-481.

Conaghan, Joanne. 2013. Law and Gender. Oxford: Oxford University Press.

Cowan, Sharon. 2005. Gender Is No Substitute for Sex: A Comparative Human Rights Analysis of the Legal Regulation of Sexual Identity. Feminist Legal Studies 13: 67-96.

Cowan, Sharon. 2008. Looking Back (To)wards the Body: Medicalization and the GRA. Social \& Legal Studies 18: 247-252.

Davy, Zowie. 2010. Transsexual Agents: Negotiating Authenticity and Embodiment Within the UK's Medicolegal System. In Transgender Identities: Towards a Social Analysis of Gender Diversity, ed. Sally Hines and Tam Sanger, 106-126. Abingdon: Routledge.

Davy, Zowie. 2011. Recognizing Transsexuals: Personal, Political and Medicolegal Embodiment. Abingdon: Ashgate.

Davy, Zowie. 2015. The DSM-5 and the Politics of Diagnosing Transpeople. Archives of Sexual Behavior 44: 1165-1176. 
Davy, Zowie, Anniken Sørlie, and Amets Suess Schwend. 2018. Democratising Diagnoses? The Role of the depathologisation Perspective in Constructing Corporeal Trans Citizenship. Critical Social Policy 38(1): 13-34.

de Young, Mary. 2010. Madness: An American History of Mental Illness and Its Treatment. Jefferson: McFarland.

Drescher, Jack, Peggy Cohen-Kettenis, and Sam Winter. 2012. Minding the Body: Situating Gender Identity Diagnoses in the ICD-11. International Review of Psychiatry 24(6): 568-577.

Drescher, Jack. 2014. Controversies in Gender Diagnoses. LGBT Health 1(1): 10-15.

Dunne, Peter. 2015. Ten Years of Gender Recognition in the United Kingdom: Still a "Model for Reform"? Public Law (4): 530-539.

Edelman, Lee. 2004. No Future: Queer Theory and the Death Drive. Durham and London: Duke University Press.

Engdahl, Ulrica. 2014. Wrong Body. Transgender Studies Quarterly 1(1-2): 267-269.

Enke, A.Finn. 2012. The Education of Little Cis: Cisgender and the Discipline of Opposing Bodies. In Transfeminist Perspectives: In and Beyond Transgender and Gender Studies, ed. A.Finn Enke, 60-77. Philadelphia: Temple University Press.

Fletcher, Ruth, Marie Fox, and Julie McCandless. 2008. Legal Embodiment: Analysing The Body of Healthcare Law. Medical Law Review 16: 321-345.

Foucault, Michel. 1998 (first published 1976). The Will to Knowledge: The History of Sexuality Volume One. Robert Hurley tr. Penguin.

Fox, Marie, and Thérèse Murphy. 2013. The Body, Bodies, Embodiment: Feminist Legal Engagement with Health. In The Ashgate Research Companion to Feminist Legal Theory, ed. Margaret Davies and Vanessa E. Munro, 249-259. Abingdon: Ashgate.

Fox, Marie, and Michael Thomson. 2017. Bodily Integrity, Embodiment, and the Regulation of Parental Choice. Journal of Law and Society 44(4): 501-531.

Garland-Thomson, Rosemarie. 2011. Misfits: A Feminist Materialist Disability Concept. Hypatia 26(3): 591-609.

Government Equalities Office (UK). 2016. Government Response to the Women and Equalities Committee Report on Transgender Equality (Cm 9301). https://www.gov.uk/government/uploads/syste m/uploads/attachment_data/file/535764/Government_Response_to_the_Women_and_Equalities _Committee_Report_on_Transgender_Equality.pdf. Accessed 11 August 2017.

Grabham, Emily. 2012. Bodily Integrity and the Surgical Management of Intersex. Body \& Society 18(2): $1-26$.

Grosz, Elizabeth. 1994. Volatile Bodies: Toward a Corporeal Feminism. Bloomington and Indianapolis: Indiana University Press.

Haraway, Donna. 1988. Situated Knowledges: The Science Question in Feminism and the Privilege of Partial Perspective. Feminist Studies 14(3): 575-599.

Harding, Rosie. 2011. Regulating Sexuality: Legal Consciousness in Lesbian and Gay Lives. Abingdon: Routledge.

Herring, Jonathan. 2014. Criminal Law: Text, Cases, and Materials. Oxford: Oxford University Press.

Hines, Sally. 2007. (Trans)forming Gender: Social Change and Transgender Citizenship. Sociological Research Online. https://doi.org/10.5153/sro.1469.

Hines, Sally. 2010. Recognising Diversity? The Gender Recognition Act and Transgender Citizenship. In Transgender Identities: Towards a Social Analysis of Gender Diversity, ed. Sally Hines and Tam Sanger, 87-105. Abingdon: Routledge.

Hines, Sally. 2013. Gender Diversity, Recognition and Citizenship. Basingstoke: Palgrave Macmillan.

Hird, Mira J. 2003. A Typical Gender Identity Conference? Some Disturbing Reports from the Therapeutic Front Lines. Feminism \& Psychology 13: 181-199.

Keeling, Amanda. 2016. Supported Decision Making: The Rights of People with Dementia. Nursing Standard 30: 38-44.

Kunak, Göksu. 2016. BODY//Opacity Politics: An Interview with Vika Kirchenbauer. http://www.berli nartlink.com/2016/04/22/body-an-interview-with-vika-kirchenbauer. Accessed 6 Mar 2017.

Lacey, Nicola. 1997. On the Subject of Sexing the Subject. In Sexing the Subject of Law, ed. Ngaire Naffine and Rosemary J. Owens. Sydney: LBC.

Lennon, Erica, and Brian J. Mistler. 2014. Cisgenderism. Transgender Studies Quarterly 1(1-2): 63-64.

Madden, Raymond. 2011. Being Ethnographic: A Guide to the Theory and Practice of Ethnography. Thousand Oaks: Sage.

Merry, Sally Engle. 1988. Legal Pluralism. Law \& Society Review 22(5): 869-896. 
Metzl, Jonathan M., and Helena Hansen. 2014. Structural Competency: Theorizing a New Medical Engagement with Stigma and Inequality. Social Science and Medicine 103: 126-133.

Ministry of Justice (DK). 2013. Kommissorium for tværministeriel arbejdsgruppe om udmøntning af regeringsgrundlagets afsnit om kønsskifte. https://panbloggen.files.wordpress.com/2013/05/kc3b8 nsskifte-kommissorium-jm.pdf\&usg=ALkJrhjLszn-4IJPOaQMon8NdRzCGtYKSA. Accessed 10 Sept 2015.

Ministry of Justice (DK). 2014. Rapport fra arbejdsgruppen om juridisk kønsskifte. http://justitsmin isteriet.dk/sites/default/files/media/Pressemeddelelser/pdf/2014/Rapport\%20om\%20juridisk $\% 20 \mathrm{k} \% \mathrm{C} 3 \%$ B8nsskifte.pdf. Accessed 21 July 2016.

Munkholm, Natalie Videbæk. 2015. Legal Status of Transsexual and Transgender Persons in Denmark. In The Legal Status of Transsexual and Transgender Persons, ed. Jens M. Scherpe, 147-182. Antwerp: Intersentia.

Naffine, Ngaire, and Rosemary J. Owens. 1997. Sexing law. In Sexing the Subject of Law, ed. Ngaire Naffine and Rosemary J. Owens, 3-21. Sydney: LBC.

Neave, Marcia. 1997. Foreword. In Sexing the Subject of Law, ed. Ngaire Naffine and Rosemary J. Owens, v-vii. Sydney: LBC.

Newsnight. 2016. Is Transgender the New Civil Rights Frontier? BBC, 5 January.

Nordmarken, Sonny. 2014. Microaggressions. Transgender Studies Quarterly 1(1-2): 129-134.

Priaulx, Nicolette. 2008. Rethinking Progenitive Conflict: Why Reproductive Autonomy Matters. Medical Law Review 16: 169-200.

Prime Minister's Office (DK). 2011. Et Danmark, Der Står Sammen. http://www.stm.dk/publikationer/ Et_Danmark_der_staar_sammen_11/Regeringsgrundlag_okt_2011.pdf. Accessed 20 Aug 2015.

Probyn, Elspeth. 1993. Sexing the Self: Gendered Positions in Cultural Studies. London and New York: Routledge.

Raun, Tobias. 2010. Screen-births: Exploring the Transformative Potential in Trans Video Blogs on YouTube. Graduate Journal of Social Science 7(2): 113-130.

Raun, Tobias. 2014. Trans as Contested Intelligibility: Interrogating How to Conduct Trans Analysis with Respectful Curiosity. Lambda Nordica 1: 13-37.

Raun, Tobias. 2016. The "Caspian Case" and Its Aftermath: Transgender People's use of Facebook to Engage Discriminatory Mainstream News Coverage in Denmark. In New Dimensions of Diversity in Nordic Culture and Society, ed. Jenny Björklund and Ursula Lindqvist, 79-103. Newcastle upon Tyne: Cambridge Scholars Publishing.

Roberts, Dorothy E. 2012. Race, Gender, and the Political Conflation of Biological and Social Issues. Du Bois Review 9(1): 235-244.

Sandford, Stella. 2005. Thinking Sex Politically: Rethinking “Sex” in Plato's Republic. South Atlantic Quarterly 104(4): 613-630.

Sandford, Stella. 2015. Philosophy and Gender. Public Lecture. Copenhagen: University of Copenhagen.

Schofield, Scott Turner. 2010. The Wrong Body. In Gender Outlaws: The Next Generation, ed. Kate Bornstein and S.Bear Bergman, 83. Berkeley: Seal Press.

Spade, Dean. 2011. Laws as Tactics. Columbia Journal of Gender and Law 21(2): 40-71.

Stryker, Susan. 2014. Biopolitics. Transgender Studies Quarterly 1(1-2): 38-42.

Sullivan, Nikki. 2014. Somatechnics. Transgender Studies Quarterly 1(1-2): 187-190.

Thaemlitz, Terre. 2013. We Are Not Welcome Here. http://comatonse.com/writings/2013_we_are_not_ welcome_here.html. Accessed 22 Feb 2017.

Thaemlitz, Terre. 2015. The Revolution Will Not Be Injected. http://comatonse.com/writings/2015_the_ revolution_will_not_be_injected.html. Accessed 24 Oct 2016.

Theilen, Jens T. 2014. Depathologisation of Transgenderism and International Human Rights Law. Human Rights Law Review 14: 327-342.

Valverde, Marianna. 2015. Chronotopes of Law: Jurisdiction, Scale and Governance. Abingdon: Routledge.

Williams, Simon J., and Gillian Bendelow. 1998. The Lived Body: Sociological Themes, Embodied Issues. London and New York: Routledge.

Women and Equalities Committee (UK). 2016. Transgender Equality (HC 390). https://publications.parli ament.uk/pa/cm201516/cmselect/cmwomeq/390/390.pdf. Accessed 11 Aug 2017.

World Health Organization. 2015. International Statistical Classification of Diseases and Related Health Problems-10. http://apps.who.int/classifications/icd10/browse/2015/en\#/F64. Accessed 10 Jan 2017. 